\title{
Developing an Effective Resume
}

A resume is one of the most important documents in your internship or job search. It is a personal marketing tool that may lead to an interview. Think of your resume as a summary of the knowledge, skills and experiences you will bring to a specific position or industry.

Format: What should my resume look like?

- Resume formats should be readable, well organized and concise. Most employers spend fewer than 20-30 seconds reviewing a resume.

- Avoid using resume templates! Creating your own document demonstrates your computer skills and initiative.. Templates can be difficult to edit, download and format over time.

- One page resumes are preferred by employers for interns and entry-level opportunities. A two page resume is acceptable for experienced candidates, and within many non-profit or academic fields.

What should my resume include?

Your resume is unique to YOU. It should include your skills, experiences and accomplishments. A resume should include:

- Contact information: Tip: Avoid using "headers" if possible, as MS Word may not print or fully download this information. Avoid text boxes as well, as this can lead to difficulty with future edits.

- Objective, Summary Statement or Skills Summary: Answers the questions, what do I want to do, where, and what can I offer?

- Education: School, Degree(s), Graduation date, or level of student (currently a Sophomore, Junior, etc.)

- Skills (optional): Describes skills that are relevant to the job sought or above and beyond what is expected.

- Experiences: Work, internship and/or volunteer experiences, accomplishments, and related leadership roles.

- Honors \& Activities: Honors/scholarships awarded, extracurricular activities and leadership roles

\section{Resume Do's and Don'ts}

\section{DO}

- Use conservative font styles (Times New Roman, Arial, Arial Narrow, or similar styles). Font size may range from 10-12.

- Set page margins between 0.5 and 1.0 inches (top, bottom, left and right).

- Use bullet points to keep text action-focused and concise.

- Include accomplishments.

- Print your resume using a laser printer; white or offwhite bond paper is preferred. (Dark paper does not copy or fax well!)

- Keep your resume up to date, with correct addresses and phone numbers!

- ALWAYS include a cover letter when mailing your resume to an employer.

- Proofread carefully!

\section{DON'T}

- Don't include personal pronouns such as I, me , or my.

- Don't include: age, marital status, height/weight, birth date, or a photograph.

- Don't abbreviate (other than for the states - SC).

- Don't exaggerate or lie on your resume. It will catch up with you.

- Don't include "References upon Request" at the bottom of your resume. Most employers who want references will ask for this. Use the space on your resume to share more details about you and your experiences.

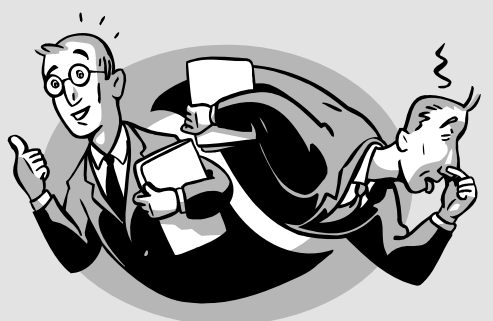




\section{Resume}

\section{OBJECTIVES, SUMMARY STATEMENTS, \& SKILLS SUMMARIES}

\section{Do you need an objective or summary?}

As a rule, the first line of your resume should communicate to the reader the type of position or industry you are seeking. If your major directly relates to the job you are seeking, (for example, you are applying for an accountant position and you are an Accounting major), you may not need an objective or summary statement.

However, for most liberal arts majors, this is not the case. For example, a Communications major may be interested in many career areas, so how does a potential employer know what types of jobs or careers would be of interest to you or what skills you have to offer for those jobs? An objective or summary is recommended in that it tells the reader the type of job/career you are targeting, and describes skills or ways you can contribute to the specific job, industry or career. If done effectively, this is a very powerful tool in getting your resume noticed.

\section{I'm including a cover letter, so do I still need an objective or summary?}

Again, although optional, an objective or summary allows you to reinforce your goals:

1. In case the employer reads your resume first; and

2. To reinforce how you meet the qualifications and the requirements of the position

\section{What is the difference between an objective statement and a summary?}

An objective statement is a concise, position centered statement describing the value you can add and the needs you can fulfill. An objective may include a brief statement of skills and qualifications that you will bring to the position. A professional summary or skills summary is longer and provides more detail than an objective statement.

Summaries identify the type of position you are seeking and provide lengthier descriptions of skills and qualifications.

\section{Objective Statement Examples:}

Seeking a statistical research position utilizing my experience with survey development and evaluating sales data.

To obtain an internship in the Human Resources field, with particular interests in recruitment and training.

\section{Professional Summary Example:}

Recent graduate with Bachelor's degree in Business and a concentration in Marketing seeking a Marketing Associate position. Offer solid understanding of marketing strategies illustrated through academic projects and an internet venture that continues to develop and test theoretical marketing strategies and business management in the areas of:

- Conceptual Planning

- Project Development
- Web-Based Marketing

- Competitive Analysis
- Advertising Campaigns

- Media/Client Relations

Skills Summary Example:

- Passionate writer and reporter. Experienced in writing feature articles, short stories, biographies, editorial pieces, press releases, research reports, and creative ad copy.

- Well-versed in copy editing, transcription/editing of interviews and proofreading, most recently as an editor for a weekly college magazine.

- Strong vocabulary and command of the English language; familiarity with MLA, Chicago, APA and Turabian writing styles

- Commitment to meeting deadlines. 


\section{What to Include}

\section{Your Name Here}

email@yourmail.edu

Permanent Address

Address

Phone
Two addresses may be used if you are at school. Avoid unprofessional email addresses.
School Address

Address

Phone

SUMMARY or OBJECTIVE

Although this section is not required, you may summarize your skills/experience in narrative or list form or tell what you are seeking. Or combine both in a summary. DO NOT USE "l"

\section{EDUCATION}

College of Charleston, Charleston, SC

Bachelor of _ Major, May 2014 (Use "Expected" date if incomplete)

Other information may include a minor(s), grade point averages, significant coursework, etc.

You may have more than one experience category, organized to focus on certain types of experiences or skills e.g. "Research Experience" or just having ONE experience section may suffice for you.

RELATED EXPERIENCE

Name of Business or Organization, City, State

Title of your position, dates or employment or experience

- What is most relevant and important to your target reader? If you have relevant experience, you may want this separate category to catch your reader's attention.

- Within each category, list your experiences in reverse-chronological order (most recent experience comes first).

- Using action verbs, write short phrases to describe what you did that illustrates each skill. Be concise and specific.

- Describe what you did, how you did it, who you did it for or with, what equipment or software you used, and what the results were.

- Identify personal strengths and skills used to achieve your accomplishments.

Name of Business or Organization, City, State

Title of your position, dates of employment or experience

- Examine your resume as a whole to determine a strategic order for the presentation of your information.

- Quantify your results, if possible, and use commonly understood terminology but no acronyms.

- Always write out or explain technical terminology and abbreviations; do not leave anything to the employer's imagination or interpretation.

- Include full or part-time experiences, volunteer work, internships, teaching experiences....

- Avoid using diluted phrases such as "responsible for" or "in charge of."

\section{ADDITIONAL EXPERIENCE}

Name of Organization, City, State

Title of your position, dates of employment or experience

- This section includes other experience which may not be relevant, but still shows experience.

\section{ACTIVITIES (OR HONORSIAWARDS OR SKILLS OR VOLUNTEER)}

List and describe organizations, position(s) held, volunteer work with dates of the experience or honors.

Depending on your experiences and skills, you could have more than one additional section listed here.

Important: Your sections and experiences should be listed in order of relevance to the job/internship. Within each section, list experience from present to past. This is an just an example and you may choose a different format to highlight your specific experience.

You may alter font sizes and margins. 


\section{Action Verbs}

Remember to use the correct verb tense

\begin{tabular}{|c|c|c|c|c|}
\hline Communication & Creative & Financial & Helping & Technical \\
\hline $\begin{array}{l}\text { Addressed } \\
\text { Arbitrated } \\
\text { Authored } \\
\text { Corresponded } \\
\text { Directed } \\
\text { Drafted } \\
\text { Edited } \\
\text { Enlisted } \\
\text { Expressed } \\
\text { Formulated } \\
\text { Influenced } \\
\text { Interpreted } \\
\text { Interviewed } \\
\text { Lectured } \\
\text { Mediated } \\
\text { Moderated } \\
\text { Negotiated } \\
\text { Persuaded } \\
\text { Presented } \\
\text { Promoted } \\
\text { Publicized }\end{array}$ & $\begin{array}{l}\text { Acted } \\
\text { Arranged } \\
\text { Conceptualized } \\
\text { Created } \\
\text { Designed } \\
\text { Developed } \\
\text { Directed } \\
\text { Engineered } \\
\text { Established } \\
\text { Fashioned } \\
\text { Founded } \\
\text { Illustrated } \\
\text { Integrated } \\
\text { Introduced } \\
\text { Invented } \\
\text { Imagined } \\
\text { Modernized } \\
\text { Originated } \\
\text { Performed } \\
\text { Planned } \\
\text { Publicized } \\
\text { Revitalized }\end{array}$ & $\begin{array}{l}\text { Accounted } \\
\text { Administered } \\
\text { Allocated } \\
\text { Analyzed } \\
\text { Appraised } \\
\text { Assessed } \\
\text { Audited } \\
\text { Balanced } \\
\text { Budgeted } \\
\text { Calculated } \\
\text { Computed } \\
\text { Developed } \\
\text { Downsized } \\
\text { Forecasted } \\
\text { Generated } \\
\text { Managed } \\
\text { Marketed } \\
\text { Planned } \\
\text { Projected } \\
\text { Researched } \\
\text { Secured }\end{array}$ & $\begin{array}{l}\text { Advised } \\
\text { Assisted } \\
\text { Clarified } \\
\text { Coached } \\
\text { Counseled } \\
\text { Developed Rapport } \\
\text { Encouraged } \\
\text { Educated } \\
\text { Empathized } \\
\text { Established } \\
\quad \text { Relationships } \\
\text { Expedited } \\
\text { Facilitated } \\
\text { Familiarized } \\
\text { Guided } \\
\text { Mentored } \\
\text { Referred } \\
\text { Rehabilitated } \\
\text { Represented } \\
\text { Supported } \\
\text { Supplied } \\
\text { Rectified }\end{array}$ & $\begin{array}{l}\text { Assembled } \\
\text { Calculated } \\
\text { Catalogued } \\
\text { Computed } \\
\text { Designed } \\
\text { Detected } \\
\text { Devised } \\
\text { Engineered } \\
\text { Fabricated } \\
\text { Integrated } \\
\text { Maintained } \\
\text { Operated } \\
\text { Programmed } \\
\text { Remodeled } \\
\text { Revamped } \\
\text { Solved } \\
\text { Streamlined } \\
\text { Trained } \\
\text { Upgraded } \\
\text { Translated }\end{array}$ \\
\hline Office Support & Research & Management & Teaching & Writing \\
\hline $\begin{array}{l}\text { Allocated } \\
\text { Approved } \\
\text { Arranged } \\
\text { Catalogued } \\
\text { Classified } \\
\text { Compiled } \\
\text { Dispatched } \\
\text { Executed } \\
\text { Formulated } \\
\text { Generated } \\
\text { Implemented } \\
\text { Inspected } \\
\text { Monitored } \\
\text { Operated } \\
\text { Organized } \\
\text { Prepared } \\
\text { Processed } \\
\text { Purchased } \\
\text { Recorded } \\
\text { Retrieved } \\
\text { Scheduled } \\
\text { Specified } \\
\text { Systematized } \\
\text { Tabulated } \\
\text { Validated }\end{array}$ & $\begin{array}{l}\text { Analyzed } \\
\text { Assessed } \\
\text { Collected } \\
\text { Compared } \\
\text { Critiqued } \\
\text { Diagnosed } \\
\text { Documented } \\
\text { Dissected } \\
\text { Evaluated } \\
\text { Examined } \\
\text { Extracted } \\
\text { Hypothesized } \\
\text { Identified } \\
\text { Inspected } \\
\text { Interpreted } \\
\text { Interviewed } \\
\text { Investigated } \\
\text { Located } \\
\text { Measured } \\
\text { Observed } \\
\text { Questioned } \\
\text { Reviewed } \\
\text { Screened } \\
\text { Summarized } \\
\text { Surveyed } \\
\text { Synthesized } \\
\text { Systematized }\end{array}$ & $\begin{array}{l}\text { Administered } \\
\text { Assigned } \\
\text { Attained } \\
\text { Authorized } \\
\text { Chaired } \\
\text { Contracted } \\
\text { Consolidated } \\
\text { Coordinated } \\
\text { Delegated } \\
\text { Developed } \\
\text { Directed } \\
\text { Evaluated } \\
\text { Executed } \\
\text { Improved } \\
\text { Increased } \\
\text { Instituted } \\
\text { Lead } \\
\text { Managed } \\
\text { Met goals } \\
\text { Organized } \\
\text { Oversaw } \\
\text { Planned } \\
\text { Prioritized } \\
\text { Produced } \\
\text { Recommended } \\
\text { Reviewed }\end{array}$ & $\begin{array}{l}\text { Adapted } \\
\text { Advised } \\
\text { Clarified } \\
\text { Coached } \\
\text { Communicated } \\
\text { Coordinated } \\
\text { Demonstrated } \\
\text { Developed } \\
\text { Educated } \\
\text { Enabled } \\
\text { Encouraged } \\
\text { Evaluated } \\
\text { Explained } \\
\text { Facilitated } \\
\text { Guided } \\
\text { Informed } \\
\text { Initiated } \\
\text { Instructed } \\
\text { Motivated } \\
\text { Persuaded } \\
\text { Presented } \\
\text { Set goals } \\
\text { Stimulated }\end{array}$ & $\begin{array}{l}\text { Addressed } \\
\text { Authored } \\
\text { Composed } \\
\text { Drafted } \\
\text { Edited } \\
\text { Formulated } \\
\text { Indited } \\
\text { Inscribed } \\
\text { Printed } \\
\text { Produced } \\
\text { Publicized } \\
\text { Recorded } \\
\text { Reproduced } \\
\text { Scribed } \\
\text { Scripted } \\
\text { Transcribed } \\
\text { Wrote }\end{array}$ \\
\hline
\end{tabular}




\title{
SAMPLE CHRONOLOGICAL RESUME
}

\section{JOSEPH FAULKNER}

\author{
232 Oak Lane, Charleston, SC 29412 • (843) 123-4567 • faulknerjl@g.cofc.edu
}

\section{SUMMARY}

Recent graduate with strong research and writing skills, as well as experience working on Capital Hill, seeking a position as a legislative assistant, with particular interests in Mid-Eastern policy and security issues.

\section{EDUCATION}

Bachelor of Arts in Political Science, May 2013

Minor in Anthropology

College of Charleston, Charleston, SC

Major GPA: $3.6 / 4.0 \quad$ Overall GPA: $3.2 / 4.0$

Related Coursework:

American Foreign Policy Process International Political Economy

Politics of Globalization American Politics and the Mass Media

\section{STUDY ABROAD}

Palestine and Arabic Studies Program, Birzeit University, West Bank, Palestine, Summer 2012

\section{HONORS}

Highly Distinguished Honor Student, 2011 - 2013

Phi Kappa Phi (Interdisciplinary Honor Society), 2012 - 2013

\section{RELEVANT EXPERIENCE}

Senior Thesis, College of Charleston, August 2012 - May 2013

- Wrote a 135 page empirical analysis of the Palestinian Authority and the Israeli Occupation of Palestine: Governing Palestine

- Required one semester of extensive research and design and one semester of writing and editing

US House of Representatives, Office of Congressman James E. Clyburn, Washington, DC Office Fellow, May - August 2012

- Provided aid to Staff Assistant and Office Coordinator, as well as occasional projects for legislative assistants and staff

- Developed working knowledge of Capitol Hill practices and procedures; gained valuable communication skills in dealing with constituent concerns

- Projects included US Farm Bill research, Medicare and Medicaid healthcare research

The Yard, College of Charleston, Charleston, SC

Staff Writer, August 2012 - May 2013

- Wrote several special interest and newspaper articles for College of Charleston student magazine

\section{ADDITIONAL EXPERIENCE}

Starbucks Coffee Co., Barista, October 2010 - May 2012

College of Charleston New Student Programs, Orientation Intern, May - August 2011

\section{SKILLS}

- Computer proficiency: Word, Access, PowerPoint, Excel, Publisher and Adobe Acrobat

- Arabic: beginner proficiency; basic literacy

\section{ACTIVITIES}

Student Government Association, College of Charleston, September 2012 - May 2013

- Acted as liaison between the student body and the Faculty Senate

This is an example of a resume in Chronological Style, which is the most common style used. All of the entries are placed in reverse chronological order, starting with newest to oldest. 


\section{SAMPLE PLAIN-TEXT}

JOSEPH FAULKNER

232 Oak Lane, Charleston, SC 29412

(843) 123-4567

faulknerjl@g.cofc.edu

\section{SUMMARY}

Recent graduate with strong research and writing skills, as well as experience working on Capital Hill, seeking a position as a legislative assistant, with particular interests in Mid-Eastern policy and security issues.

\section{EDUCATION}

Bachelor of Arts in Political Science, May 2013

Minor in Anthropology

College of Charleston, Charleston, SC

Major GPA: $3.6 / 4.0$

Overall GPA: $3.2 / 4.0$

Related Coursework: American Foreign Policy Process, International Political Economy, Politics of Globalization, American Politics and the Mass Media

\section{STUDY ABROAD}

Palestine and Arabic Studies Program, Birzeit University, West Bank, Palestine, Summer 2012

\section{HONORS}

Highly Distinguished Honor Student, 2011 - 2013

Phi Kappa Phi (Interdisciplinary Honor Society), 2012- 2013

\section{RELEVANT EXPERIENCE}

Senior Thesis, College of Charleston, August 2013 - May 2013

* Wrote a 135 page empirical analysis of the Palestinian Authority and the Israeli Occupation of Palestine entitled Governing Palestine

* Required one semester of extensive research and design and one semester of writing and editing

US House of Representatives, Office of Congressman James E. Clyburn, Washington, DC

Office Fellow, May - August 2012

* Provided aid to Staff Assistant and Office Coordinator, as well as occasional projects for legislative assistants and staff

* Developed working knowledge of Capitol Hill practices and procedures; gained valuable communication skills in dealing with constituent concerns

${ }^{*}$ Projects included US Farm Bill research, Medicare and Medicaid healthcare research

George Street Observer, College of Charleston, Charleston, SC

Staff Writer, August 2012 - May 2013

* Wrote several special interest and newspaper articles for College of Charleston weekly newspaper

\section{ADDITIONAL EXPERIENCE}

Starbucks Coffee Co., Barista, October 2010 - May 2012

College of Charleston New Student Programs, Orientation Intern, May - August 2008

SKILLS

* Computer proficiency: Word, Access, PowerPoint, Excel, Publisher and Adobe Acrobat

* Arabic: beginner proficiency; basic literacy

\section{ACTIVITIES}

Student Government Association, College of Charleston, September 2012 - May 2013

* Acted as liaison between the student body and the Faculty Senate

Note: Plain text resumes may be more than one page, as they are typically being scanned into a computer database rather than read by a person. The words are in left justification with only bold face or all caps to set sections apart. 


\section{Summary of Qualifications}

- Experience in designing public relations materials: press releases, newsletters, surveys, and brochures

- Knowledge of cutting edge social media platforms including FaceBook, Twitter and YouTube

- Comfortable with public speaking; excellent oral and written communication skills

- Computer literate in Microsoft Office programs, InDesign, Photoshop and Illustrator

\section{Education}

College of Charleston, Charleston, SC

Bachelor of Science in Communication, May 2013

Minor: French

Paris University, Paris, France

Study Abroad, Summer 2012

- Video Production Course: Gained experience in camera usage, shot variety, and editing in the production of video projects: A Traveler's Excursion and Secrets of Henry the First

\section{Relevant Knowledge}

Public Relations Campaigns, College of Charleston, Spring 2013

- Organized a campaign for a local non-profit to increase visibility and donations

- Created different media to promote annual fundraising drive: brochures, press releases, and news articles

\section{Experience}

Anderson Communications, New York, New York

Public Relations Intern, Summer, 2013

- Categorized and chronicled media mentions of current clients in New York publications

- Posted public relations updates on social media sites including Facebook, Twitter and YouTube

- Researched new social media and mobile applications

- Created and maintained editorial calendars, events calendars, and client database

- Assembled and distributed press kits including press releases and pitch letters

Piccolo Spoleto Festival, Charleston, SC

Intern, May - June 2011

- Distributed ticket brochures, program guides and marketing materials for annual arts festival

- Managed the press room during the festival; scheduled interviews; packaged and distributed press kits

- Served as the house/event manager for over 28 theatrical, art, and dance productions

\section{Work Abroad Experience}

Collège François Premier, Villers-Cotterêts, France

Foreign Language Assistant, May - August 2012

- Organized, planned, and taught classes in a foreign language program

- Strengthened French communications skills by living with a native family

\section{Activities}

Zeta Tau Alpha Sorority, 2012 - Present

- Act as Alumni Relations chair, contacting past members and creating newsletters

- Volunteer at various philanthropic events for the Charleston Animal Society, Breast Cancer Awareness Week, and the Ronald McDonald House

\section{Note: Jessica chose to add a "Summary of Qualifications" section to point out several skills needed in} the Public Relations field; she also wanted to emphasize her international experience. 


\section{OBJECTIVE}

To contribute relevant experience, educational background, and linguistic skills to a Teaching of English as a Second Language position in Japan

\section{SKILLS AND ACCOMPLISHMENTS}

\section{Teaching and Leadership:}

- Established advanced classroom management skills to ensure successful teaching of associates

- Cross-trained, supervised, and evaluated activities of associates (20-25) of various ethnic backgrounds

- Provided group/one-on-one intensive training to new associates, including classroom instruction/workshops, mentoring and providing feedback to associates, and facilitating presentations

- Oversaw and coordinated receiving supplies, proper storage/rotation, food and drink preparation, production, and quality

- Managed and coordinated daily shift operations for full service area restaurant, including training and supervising employees (15-18)

\section{Languages and Computer Skills:}

- Native fluent in English and extensive language training in Japanese including all hiragana, katakana, 300+ kanji, and conversational skills in business and colloquial Japanese

- Successfully tutored Japanese and English students in English and Japanese respectively

- Translated entire literary works from Japanese to English including Kitchen by Yoshimoto Banana

- Proficient/knowledgeable: Microsoft Windows XP, Office XP (Word, Excel, PowerPoint), and various in-house center programs and databases in Japanese and English

\section{Customer Service:}

- Provided excellent customer service support including professional handling of a call center's customer inquiries, credit authorizations, and resolving payment/billing and escalated account issues

- Assisted in managing daily operations and customer service department, ensuring optimum service and satisfaction of an upscale restaurant

- Educated service staff to augment customer service by increasing profits through suggestive selling

- Accountable for development of employees, sales and customer service at Starbucks establishments, with annual sales revenue up to $\$ 1,500,000$

\section{EDUCATION}

Bachelor of Science in International Business, Minor in Japanese a GPA: 3.6

College of Charleston, Charleston, SC - May 2013

Activities: College of Charleston Japanese Club and International Club

\section{WORK EXPERIENCE}

Starbucks Coffee Co., Summerville, SC

McAlister's Deli, Summerville, SC

First Data, Summerville, SC
Certified Barista

Waiter

CSR/Associate Trainer
November 2012 - Present

June 2011- November 2012

June 2010- February 2011

Note: Amber's work experience is not relevant to what she is seeking; so she chose to highlight her skills and accomplishments in order to better communicate her qualifications for a teaching abroad position. 
JASON VARITEK

varitek@g.cofc.edu

(843) 789-3654
LOCAL

18 Central Avenue

Charleston, SC 29402
PERMANENT

1449 Jules Avenue

Ravenel, SC 29470

\section{SUMMARY}

Rising senior with interest and knowledge of supply chain management, procurement, and global commerce, as well as strong leadership and teamwork skills seeking an internship in the transportation industry.

\section{EDUCATION}

Bachelor of Science in International Business, May 2014

Minor: Global Logistics and Transportation

College of Charleston, Charleston, SC

\section{RELEVANT KNOWLEDGE}

Global Commerce and Enterprise, College of Charleston, Spring 2013

- Designed a project to export a local tea product to the international market

- Analyzed industries and markets; facilitated the transportation of the product through the exportation process

- Completed the necessary export documentation including the Bill of Lading and the Certificate of Origin

Designing and Managing the Supply Chain, College of Charleston, Fall 2012

- Analyzed different aspects of the supply chain including distribution strategies, risk pooling, procurement strategies, and distributor integration

- Performed calculations using the centroid method to determine optimal warehouse locations as well as resource applications

\section{ACTIVITIES}

Alpha Pi Omega

President/Vice President of Administration, 2012 - present

- Led the organization in coordination and participation of numerous service projects throughout the Charleston area

- Organized and facilitated weekly meetings; delegated tasks and empowered fraternity members

- Increased membership to nearly double its previous size

Student Port Club, 2012 - present

Finance Club, 2012 - present

\section{WORK EXPERIENCE}

Boulevard Diner, Charleston, SC

Server, August 2011 - present

- Worked effectively with restaurant team members to ensure customer satisfaction in a fast-paced environment

- Managed and reconciled individual daily sales between cash and Point of Sale computer system

- Trained new employees on responsibilities and general safety procedures

\section{REFERENCES}

Available upon request

Note: Jason doesn't have much work experience, so he is focusing on the knowledge he has gained from classes in his major. The one job he has held is not related to his objective, but he has listed the job responsibilities that most closely relate. 


\section{Christine Edwards}

edwardscb@g.cofc.edu - (803) 271-2712

School: 178 Green Street, Charleston, SC 29424

Permanent: 199 Pleasant Drive, Columbia, SC 29615

Objective

Computer

Skills

Work

Experience

Education

Activities
To obtain an internship in information technology utilizing programming and communication skills

Programming Languages: Java, C++, PHP, HTML Tools: Microsoft Office (Access, Excel, Word, PowerPoint), Adobe Creative Suite, DreamWeaver; Cascade; MS Visual Studio Operating Systems: Windows 7/XP, LINUX, UNIX

Information Technology Assistant, September 2013 - present

APAC Manufacturing Company, Charleston, SC

- Assist Computer Support team in writing a payroll program utilizing $\mathrm{C}++$ language and programming codes

- Set up database in Access in order to maintain employee information including names, addresses, hire dates, and other necessary information; ability to cross reference and search

- Gain exposure to a variety of software applications, as well as hardware requirements, in a business setting

Student Assistant Web Master, Summer 2013

Department of Student Life, Charleston, SC

- Developed new web pages in Cascade Server web content management system under direction of the Division Webmaster

- Developed forms to collect data online using PHP and error checking with JavaScript

Visitor Greeter, August 2011 - May 2013

Charleston Visitor Center, Charleston, SC

- Provided information about the Charleston area to visitors, answered questions, gave directions

College of Charleston, Charleston, SC Bachelor of Arts in Philosophy, Minor in German, May 2014

Elective coursework in computer science/computer information systems

Philosophy Club, Fall 2012 - Present

Habitat for Humanity, Spring 2013

Note: Christine's major is not directly related to her job objective, so she put her related skills and experience first in order to attract the reader's attention. 


\section{E-mail Resume Tips}

\section{E-mail makes it possible for you to respond instantly to an opportunity, but if not done correctly, your resume may be overlooked or deleted before it is read.}

Whenever possible, copy a plain text resume into the body of your e-mail message, rather than sending your resume as an attachment. Why?

- Attachments may contain viruses, particularly if they are in Microsoft Word.

- Firewalls may stop e-mail attachments from entering a company network.

- Recruiters may not take the time to open the attachment.

\section{CREATE A PLAIN TEXT RESUME AND COVER LETTER}

A text resume will be stripped of formatting features such as bold and italics, so it may not appear very attractive to you. However, it will be universally compatible with all systems. To convert your resume from MS Word to plain text:

- Open your resume document, go to Edit > Select All and change the font to Courier 12 point; go to File > Page Setup and change the left and right margins to 1.5 inches.

- Go to File > Save As > under "Save as Type," select "Plain Text."

- Select "yes" at the prompt that warns about features being compatible.

- Name and save this file, then reopen the file, which should now have a text (.txt) extension.

- Review and clean up your document:

- Insert space where necessary

- Change bullets to asterisks or dashes

- Left-justify all text

- Change or remove symbols that didn't convert properly

- Take out tabs and centering

- Save your work!

\section{TEST THE FILE}

Open your text resume, copy and paste it into your email message box and send it to yourself and a few friends to ensure that the text transfers properly.

\section{CREATE THE E-MAIL MESSAGE}

Follow the employers' directions for applying to each position! Requirements and instructions will differ, based on the individual company's needs. If no specific instructions are given:

- Open your email program and set the message format to plain text, not HTML.

- Make the message Subject memorable! 'My resume" isn't going to grab the attention of busy person. Make the subject line relevant, and include your name, e.g. "Resume of Jane Smith - Copy Editor position."

- Now create a "cover letter" message just as you would in print, except leave off your mailing address, the date, and the recipient's mailing address. The message will begin with the salutation, e.g.: "Dear Mr. Jones:"

- Type your "signature" at the bottom of your "cover letter". Avoid clever quotations/sayings in your email signature.

- After your signature, add a couple of blank lines and the text notation.

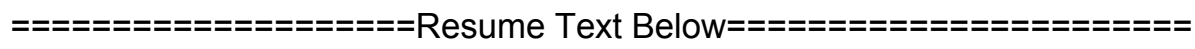

- Add a couple more blank lines, then paste the text from your ASCIl resume into the body of the email message.

- Unless the employer has requested no attachments, attach your resume (in Word or PDF format). This will accommodate employers who prefer a traditional resume. It doesn't hurt to send your resume in both formats!

Tip: When posting a resume to an online resume builder, use your plain text resume, and cut and paste it to fill the online form. 


\section{Resume Planning Worksheet - Traditional Resume}

Identifying information:

first name, middle initial, last name

current address, telephone number, e-mail address

permanent address, telephone number

OBJECTIVE

A (An) $x$ position utilizing my $x, y$, and $z$ skills OR A position in $x$ that would benefit from my $x$ and $y$ experience

EDUCATION

college, city, state

degree, month, year to be received

major(s), minor(s), concentration(s)

grade point average (if above a 3.0)

related coursework (maximum of 6 classes; only if applicable to objective)

EXPERIENCE (volunteer or paid. List most recent experience first.)

title, name of organization, city, state, and dates of employment

leading with an action verb, describe what you did at the organization

describe another responsibility or duty

describe another responsibility or duty

describe another responsibility or duty

(over) 
title, name of organization, city, state, and dates of employment

leading with an action verb, describe what you did at the organization

describe another responsibility or duty

describe another responsibility or duty

title, name of organization, city, state, and dates of employment

leading with an action verb, describe what you did at the organization

describe another responsibility or duty

describe another responsibility or duty

SKILLS (specify computer languages or special skills, including working knowledge, proficiency, or fluency in languages other than English)

ACTIVITIES (list leadership positions, memberships or affiliations)

name of organization, title or position (if applicable)

name of organization, title or position (if applicable)

name of organization, title or position (if applicable)

HONORS AND AWARDS (if listing awards, tell the employer what the award was for)

name of honor or award, date received

name of honor or award, date received

name of honor or award, date received

REFERENCES Available upon request 